\title{
Tracheoesophageal Fistula Secondary to Tuberculosis: A Case Report
}

\author{
Tüberküloza Sekonder Trakeoözefageal Fistül: Olgu Sunumu
}

Mutlu Onur Güçsav', Mine Gayaf', Nimet Aksel', Kenan Can Ceylan², Dursun Alizoroğlu'

\begin{abstract}
A tracheoesophageal fistula (TEF) is a pathological connection between the trachea and esophagus. Infectious diseases rarely lead to TEF, and tuberculosis is the most common cause of TEF among all infectious causes. A 78-year-old male patient under examination for esophageal malignancy at the gastroenterology service, and who was expected to undergo an endoscopic biopsy, was diagnosed with aspiration pneumonia after complaints of dyspnea and coughing after liquid intake, and was transferred to chest diseases clinic. TEF was identified from a bronchoscopy. Mycobacterium tuberculosis DNA was isolated during a bronchial aspiration. An endoscopic biopsy, performed after esophageal malignancy was suspected, gave the result of a granulomatous reaction. The patient was diagnosed with tuberculosisinduced TEF. Anti-tuberculosis treatment was initiated, and a tracheal $Y$ stent was fitted. In this article we present a rare case in which a TEF emerged secondary to tuberculosis, and suggest that tuberculosis may be a cause of TEF. It is advised that before starting invasive surgical TEF treatment, it is essential to take the necessary precautions.
\end{abstract}

Key words: Aspiration pneumonia, Trachea esophageal fistula, tuberculosis, tracheal stent.

\section{Özet}

Trakeaözofageal fistül (TÖF) trakea ile özefagus arasında patolojik bir bağlantı olmasıdır. Enfeksiyon hastalıklarına sekonder gelişen TÖF çok nadir nedenlerdendir. Tüberküloz enfeksiyonu ise enfeksiyöz nedenler arasında en sık izlenenidir. Gastroenteroloji servisinde özefagus malignitesi ön tanısı ile tetkik edilen ve endoskopik biyopsi sonucu beklenen 78 yaşında erkek hasta nefes darlığı, sıvı gıda aldıktan sonra olan öksürük yakınması olması üzerine yapılan tetkiklerde aspirasyon pnömonisi tanısı aldı ve göğüs hastalıkları servisine nakil alındı. Bronkoskopisi yapıldı. TÖF ağzı görüldü. Bronş aspirasyonunda mycobacterium tuberculosis DNA'sı saptandı. Endoskopik biyopsi sonucu granülamatöz reaksiyon olarak geldi. Hastaya tüberküloz nedenli TÖF tanısı konuldu. Antitüberküloz tedavisi başlanan hastaya trakeal $Y$ stent takıldı. Makalemizi tüberkülozun nadir görülen bir TÖF nedeni olması ve nedeni bilinmeyen TÖF'ün operasyonu öncesinde tüberküloz bulaşına yönelik gerekli önlemlerin alınmasının önemini vurgulamak amaciyla sunuyoruz.

Anahtar Sözcükler: Aspirasyon pnömonisi, trakeoözefageal fistül, tüberküloz, trakeal stent.
'Department of Chest Diseases, Health Sciences University Dr Suat Seren Chest Diseases and Chest Surgery Training and Research Hospital, İzmir, Turkey

${ }^{2}$ Department of Thoracic Surgery, Health Sciences University Dr Suat Seren Chest Diseases and Chest Surgery Training and Research Hospital, İzmir, Turkey

\author{
'Sağlık Bilimleri Üniversitesi Dr. Suat Seren Göğüs Hastalıkları \\ ve Cerrahisi Eğitim Araştırma Hastanesi, Göğ̈̈s Hastalıkları \\ Kliniği, İzmir \\ ${ }^{2}$ Sağlık Bilimleri Üniversitesi Dr. Suat Seren Göğüs Hastalıkları \\ ve Cerrahisi Eğitim Araştırma Hastanesi, Göğüs Cerrahisi \\ Kliniği, İzmir
}

Submitted (Başvuru tarihi): 19.12.2018 Accepted (Kabul tarihi): 01.04.2019

Correspondence (iletişim): Mutlu Onur Güçsav, Department of Chest Diseases, Health Sciences University Dr Suat Seren Chest Diseases and Chest Surgery Training and Research Hospital, İzmir, Turkey

e-mail: mutluonur.gucsav@saglik.gov.tr 
A tracheoesophageal fistula (TEF) is a rare pathological tract between the tra-chea and the esophagus. TEF can be either congenital or acquired, although the former is more common, occurring as a result of an abnormality in the devel-opment of the septum between the ventral tube and the dorsal esophagus in the embryological period, and is observed in around one of every 5,500-6,000 births $(1,2)$. Acquired TEF can develop secondary to tracheal intubation, ma-lignancy, granulomatous mediastinal infections, immunodeficiency syndromes, open and closed chest traumas, and iatrogenic trauma. Primary esophagus or lung cancers, or the treatment of such mediastinal tumors as lymphoma, ac-count for $50-70 \%$ of all acquired TEF cases, while TEF development due to tuberculosis is a rare condition. The most significant symptom is recurrent coughing followed by fluid intake. Aspiration pneumonia, sepsis and mediasti-nitis secondary to recurrent aspirations are the most severe complications, caus-ing severe morbidity and mortality. Emergency treatment should be planned as soon as TEF is diagnosed. In this article we present a case study and the treatment plan of a patient who was diagnosed with TEF secondary to tuberculosis, which is very rare.

\section{CASE}

A 78-year-old male patient was admitted to the gastroenterology department with a pre-diagnosis of esophageal carcinoma. During hospitalization, the patient re-vealed the following symptoms: dyspnea, cough, difficulty in swallowing solid-liquid foods, and sputum. He was transferred to the chest diseases clinic with a preliminary diagnosis of aspiration pneumonia. The patient's history and family history were normal. Upon physical examination, the patient was dehydrated and cachectic, and the skin turgor tone was decreased.

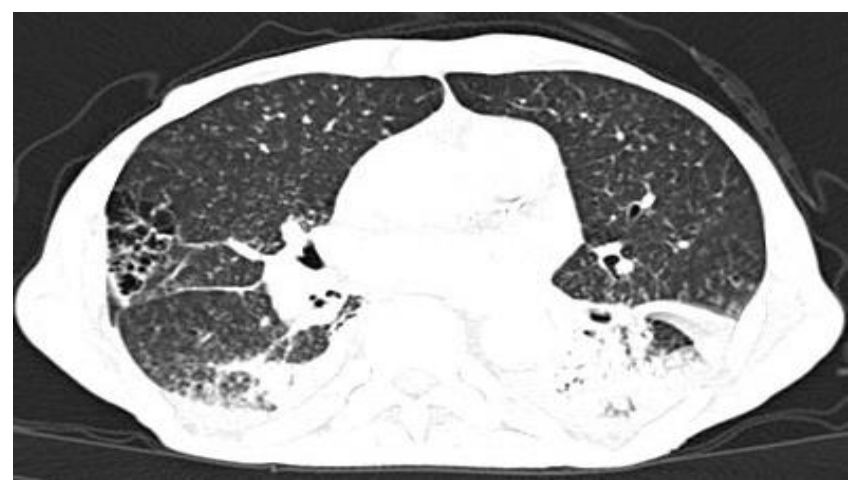

Figure 1a: Consolidated areas including air bronchograms in the lower lobes of both lungs but more dominant on the left side

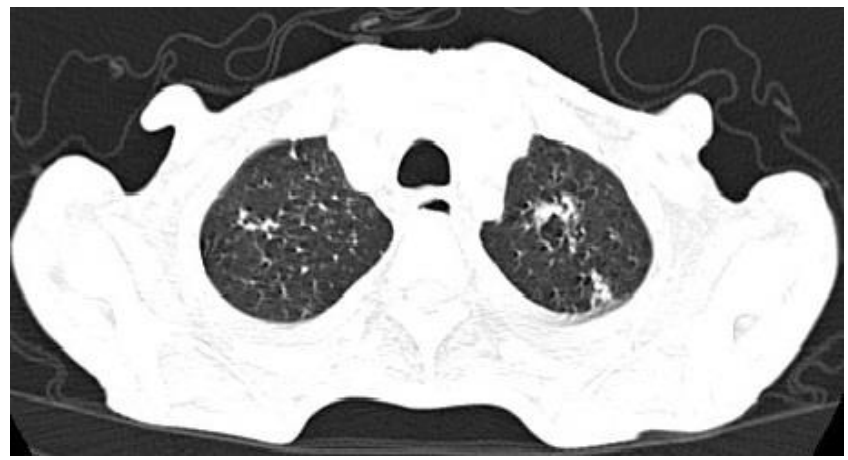

Figure 1b: Nodular appearance in the upper lobes of both lungs

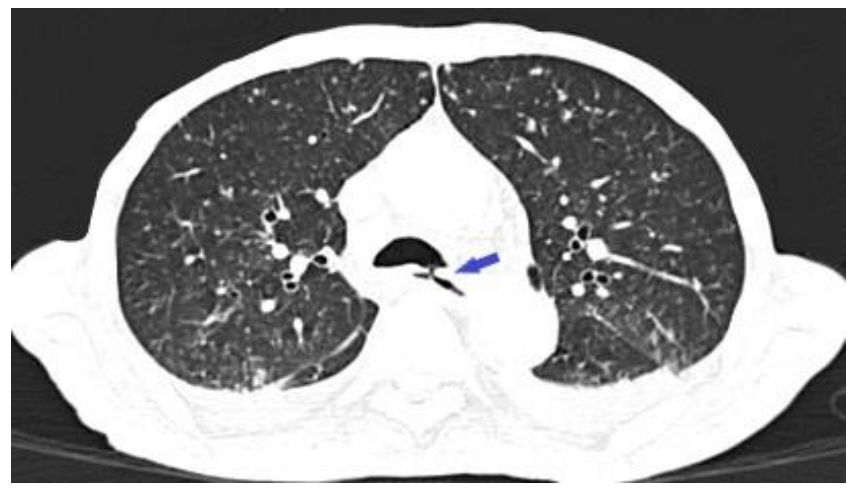

Figure 1c: A connective structure between the left main bronchus posterior and esophagus suggesting TEF

A respiratory system examination revealed the presence of rales in the lower areas of both lungs. Laboratory tests revealed the following results: $\mathrm{Hb}: 10.1 \mathrm{~g} / \mathrm{dl}$, plate-let: 109,000 dL, urea: $69 \mathrm{mg} / \mathrm{dl}, \mathrm{AST}: 42 \mathrm{U} / \mathrm{L}, \mathrm{ALT}:$ 52, Ca: $7.6 \mathrm{mg} / \mathrm{dl}$, protein: $4.4 \mathrm{~g} / \mathrm{dl}$, albumin: 2.1. CRP value was increased $(20.92 \mathrm{mg} / \mathrm{dl})$, other parameters were in the normal range.

A scattered patchy opacity was observed in both lungs in a postero-anterior chest $X$-ray. Ceftriaxone $1 \times 2 \mathrm{gr}$, clindamycin $600 \mathrm{mg} 3 \times 1 \mathrm{IV}$ and total parenteral nutri-tion treatments were initiated. An endoscopy revealed a mucosal ulceration at the $25 \mathrm{th} \mathrm{cm}$ of the esophagus and a 9 $\mathrm{mm}$ scope was unable to pass through this nar-rowed passage. A thorax computed tomography (CT) of the patient revealed con-solidated areas that included air bronchograms in the lower lobes of both lungs that were more dominant on the left side (Figure 1a), as well as a peribronchial nodular appearance in the upper lobes of both lungs (Figure 1b). In the mediastinal frame, retrotracheal, left lower paratracheal and subcarinal lymph nodes were identified. Esophageal wall thickness was also increased, and a fistula was identi-fied between the posterior tracheal wall and the esophagus suggesting, TEF at the carinal level (Figure 1c).

During the performed bronchoscopy, two large fistula orifices were observed at the posterior of the left main 
bronchus (Figure 2a and b). Dense mucopurulent sputum was aspirated, especially from the left main bronchus inlet. In a bronchial aspiration, an acid-resistant bacillus (ARB) was negative, but Mycobacterium tu-berculosis DNA was detected via a polymerase chain reaction (PCR). An NG catheter was inserted to continue feeding. The patient consulted a thoracic sur-geon, and after further evaluation, the patient was considered suitable for a tra-cheal stent application. A tracheal $Y$ stent was subsequently applied via rigid bronchoscopy.

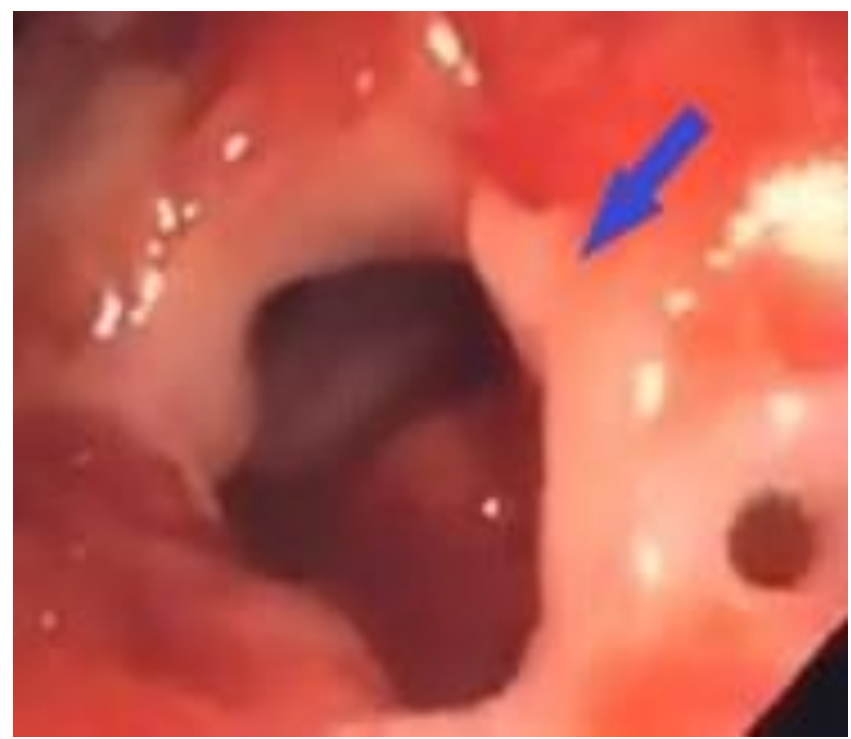

Figure 2a: Two fistula orifices were observed at the posterior of the left main bronchus

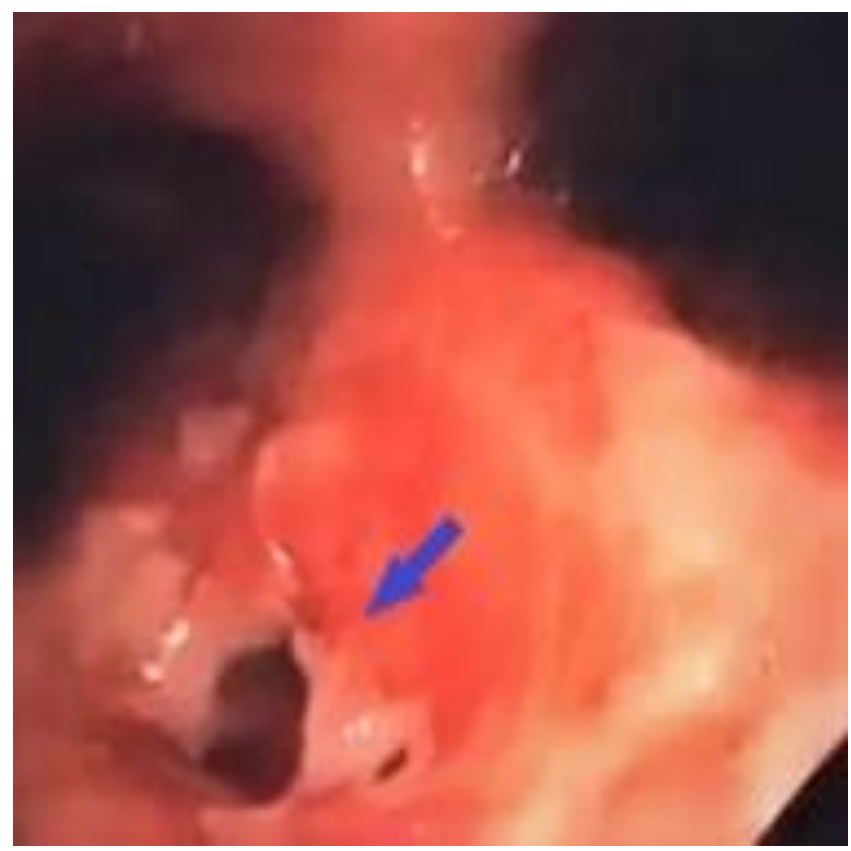

Figure2b: Two fistula orifices were observed at the posterior of the left main bronchus
Endoscopic biopsy specimens showed excessive fibrinopurulent exudate as well as ulceration, a squamous epithelial fragment with reactive cellular changes, and a granulomatous reaction. No neoplastic epithelial cell infiltration was detected. The patient was diagnosed with TEF secondary to tuberculosis. Anti-tuberculosis treatment was initiated, and the patient was transferred to the tuberculosis clinic.

Endoscopy was performed again for further investigation. An approximate 7-8 mm TEF orifice was observed 25-26 $\mathrm{cm}$ distant to the cutting teeth. NG provided nutrition and PEG was planned for long-term feeding. The patient was consulted by a gastroenterologist. The patient was referred to the center where the PEG pro-cedure was performed. After not attending the follow-up, the patient was report-ed to have been found dead at home after a month.

\section{DISCUSSION}

Both the diagnosis and treatment of TEF are difficult for clinicians. TEF frequent-ly presents with recurrent lower respiratory tract infections. The most common symptom is recurrent coughing, especially after fluid intake. Some patients may suppress coughing by lying in the supine position (Ono sign). Digestive system symptoms are rarer, with epigastric sensitivity and reflux being the most common, resulting from the stomach filling with air during expiration $(3,4)$. Recurrent aspi-rations and aspiration pneumonia may also lead to such serious complications as sepsis and mediastinitis. For this reason, oral intake should be ceased immediately if TEF is suspected. Our case presented with a recurrent cough and aspiration pneumonia after fluid intake; and oral intake was stopped immediately.

Percutaneous vertebroplasty has been widely used for the operative treatment of vertebral fractures over the past 30 years, having gained popularity as a method bringing immediate pain relief $(6,7)$. Transvertebral cement leakages into the surrounding tissues and into the paravertebral veins are common complications after percutaneous TEF can be classified as congenital or acquired. Some $49 \%$ of the acquired causes are malignancies, while the remaining are trauma, tuberculosis, actinomycosis and esophageal diverticulum (5). Tuberculosis-induced TEF cases are rare (6), while tuberculosis-dependent TEF may occur due to endobronchial tuberculosis, medias-tinal lymph node tuberculosis or esophageal tuberculosis. 
Tuberculoid mediastinal lymphadenopathy, which can cause necrosis and perforation of the adjacent struc-ture, is an important pathogenetic factor in fistula formation (7). Esophagus-originated tuberculosis is usually seen in immunocompromised patients, and may cause fistulas by abrading the adjacent tracheobronchial tree (8). Although our pa-tient presented with radiologic parenchymal tuberculosis finding, no pathological area was found that suggested endobronchial tuberculosis in bronchoscopy. The most probable hypothesis for our patient is that an infection in the mediastinal pathological lymph nodes between the esophagus and the trachea created a fistula between the trachea and the esophagus, although another possibility is that it was induced by endobronchial tuberculosis due to the weakening of the immune sys-tem of this old patient.

The opening of the fistula is usually located on the posterior wall of the trachea. In our patient, two large openings, one bigger and one smaller, were observed at the posterior of the left main bronchus entrance at the carina level. Esophageal tuber-culosis is mostly associated with mediastinal lymphadenopathy, and trache-oesophageal and/or esophageal-mediastinal fistulas are present in half of such cas-es (9). Our patient was initially thought to have an esophageal carcinoma, but was eventually diagnosed with a TEF. Although esophageal malignancy was thought to be the cause, the endoscopic biopsy resulted with a granulomatous reaction, and so it was considered that the cause of the TEF may be a non-malignant, granulom-atous infection, such as tuberculosis. The detection of the DNA of Mycobacterium Tuberculosis in the deep tracheal aspiration via PCR confirmed the diagnosis of tuberculosis.

Although surgery was the most common treatment in the past, endoscopic and bronchoscopic stent applications are today the most common modalities. The risk and difficulty of surgery and the long anesthesia times play a key role in surgical decisions as a second option (10). Laser and argon plasma coagulation are other options for the treatment of small fistulas, but due to the potential for the expan-sion of the fistula, they should be applied by experts, taking due care (11). Treat-ment should be planned as soon as possible after the confirmation of a TEF diag-nosis, and the primary cause should be ascertained, after which, the treatment of the primary cause should be added to the interventional therapies. This approach decreases both mortality and morbidity rates. In our patient, after confirming the diagnosis of TEF, intervention modalities were performed immediately to prevent aspiration. After the primary cause was found to be tuberculosis, anti-tuberculosis treatment was started.

In countries such as ours, where the incidence of tuberculosis is still high, tubercu-losis should be considered in the etiology of TEF. Owing to the need for an inter-ventional procedure for the immediate repair of a fistula, and the amount of time needed for a definitive diagnosis of tuberculosis being long in patients with TEF, it is essential that health workers remember that tuberculosis is a cause of TEF, and to take the necessary precautions prior to surgical and bronchoscopic proce-dures.

\section{CONFLICTS OF INTEREST}

None declared.

\section{AUTHOR CONTRIBUTIONS}

Concept - M.O.G., M.G., N.A., K.C.C., D.A.; Planning and Design - M.O.G., M.G., N.A., K.C.C., D.A.; Supervision - M.O.G., M.G., N.A., K.C.C., D.A.; Funding M.G., N.A., M.O.G.; Materials - M.O.G., M.G., N.A.; Data Collection and/or Processing - M.O.G., M.G.; Analysis and/or Interpretation - M.O.G., M.G.; Literature Review - M.O.G., M.G.; Writing - M.O.G.; Critical Review - M.O.G., M.G.

\section{YAZAR KATKILARI}

Fikir - M.O.G., M.G., N.A., K.C.C., D.A.; Tasarım ve Dizayn - M.O.G., M.G., N.A., K.C.C., D.A.; Denetleme M.O.G., M.G., N.A., K.C.C., D.A.; Kaynaklar - M.G., N.A., M.O.G.; Malzemeler - M.O.G., M.G., N.A.; Veri Toplama ve/veya İşleme - M.O.G., M.G.; Analiz ve/veya Yorum - M.O.G., M.G.; Literatür Taraması - M.O.G., M.G.; Yazıyı Yazan - M.O.G.; Eleştirel İnceleme M.O.G., M.G.

\section{REFERENCES}

1. Özden $O$, Gün I. Trakeoözefageal fistül; Olgu sunumu. Bakırköy Tıp Dergisi 2014; 10:82-4. [CrossRef]

2. Taşkınlar H, Kıllı I, Çelik Y, Avlan D, Naycı A. Özofagus atrezisi ve trakeoö-zofageal fistüllü hastalardaki deneyimlerimiz. Çocuk Cerrahisi Dergisi 2012; 26:32-6. [CrossRef]

3. Reed MF, Mathisen DJ. Tracheoesophageal fistula. Chest Surg Clin N Am 2003; 13:271-89. [CrossRef]

4. Braimbridge MV, Keith HI. Oesophago-bronchial fistula in the adult. Thorax 1965: 20:226-33. [CrossRef] 
5. Hutchin P, Lindskog GE. Acquired esophagobronchial fistula of infectious ori-gin. J Thorac Cardiovasc Surg 1964; 48:1-12.

6. Martins A, Gonçalves Á, Almeida T, Fazeres F, Midões A. Bronchoesophageal fistula in the setting of tuberculosis infection. J Gastrointest Surg 2017; 21:2119-21. [CrossRef]

7. Indiran V. Tuberculous bronchoesophageal fistula presenting as intractable co-ugh. Tuberk Toraks 2017; 65:60-2. [CrossRef]

8. Gaissert HA, Roper CL, Patterson GA, Grillo HC. Infectious necrotizing esop-hagitis: outcome after medical and surgical intervention. Ann Thorac Surg 2003; 75:342-7. [CrossRef]
9. Devarbhavi HC, Alvares JF, Radhikadevi M. Esophageal tuberculosis associa-ted with esophagotracheal or esophagomediastinal fistula: report of 10 cases. Gastrointest Endosc 2003; 57:588-92. [CrossRef]

10. Freitag L, Tekolf E, Steveling H, Donovan TJ, Stamatis G. Management of malignant esophagotracheal fistulas with airway stenting and double stenting. Chest 1996; 110:1 155-60. [CrossRef]

11. Rakoczy G, Brown B, Barman D, Howell T, Shabani A, Khalil B, et al. KTP laser: an important tool in refractory recurrent tracheo-esophageal fistula in child-ren. Int J Pediatr Otorhinolaryngol 2010; 74:326-7. [CrossRef] 